\title{
A CRITICAL ANALYSIS OF IMAM RABBANI AHMAD SIRHINDI'S DOCTRINES ON SUFISM
}

\author{
Saeyd Rashed Hasan Chowdury \\ Institute of Social Sciences, Ankara University, Turkey \\ E-mail: rashedchowdury@ankara.edu.tr \\ Vahit Göktaş \\ Institute of Social Sciences, Ankara University, Turkey \\ E-mail: rashedchowdury@ankara.edu.tr
}

\begin{abstract}
The purpose of this study is to present an analysis of the teachings and ideals of the life and thought of Imam Rabbani Ahmad Sirhindi's followers inspires the Muslims of the present world to pursue the path of truth, welfare, and justice. We tried to collect data from secondary sources and found that various superstitions entered Sufism when many non-Islamic issues permeated Islam. Imam Rabbani has made tireless efforts in writings and discourses through Sufism to return Islam to its original purity. He was awarded the title of "Reformer of the second millennium" because he first introduced Islamic thought in the history of the Indian subcontinent. On the other hand, Imam Rabbani taught the Wablat al-Shubüd doctrine by criticizing the Waḅdat al-Wujüd doctrine introduced by Ibn 'Arabī. As he continued the pure tradition of religion by subverting the superstitions of sharia in Islam, he established "Mujaddidiya Tariqa" in the spiritual world and coordinated the shariatariqa in Sufism. However, the outcome of our research shows how Imam Rabbani builds equality of status, love, and fraternity and instructs people through Sufism to respect the religion, emotions, and practices of others.
\end{abstract}

Keywords: Ahmad Sirhindi; Sufism; Sufi Movement; The Indian Subcontinent; Waḅdat al-Shubüd; Waḅdat al-Wujūd.

Article history: Received: 07 January 2020 | Revised: 12 February 2021 Accapted: 06 May 2021 | Available online: 02 June 2021

\section{How to cite this article:}

Chowdury, Saeyd Rashed Hasan, and Vahit Göktaş. "A Critical Analysis of Imam Rabbani Ahmad Sirhindi's Doctrines on Sufism”. Teosofi: Jurnal Tasawuf dan Pemikiran Islam 11, no. 1 (2021): 93-121. https://doi.org/10.15642/teosofi.2021.11.1.93-121. 


\section{Introduction}

There have been some great men in the history of Islam who have helped build a multi-faceted society. One of them is Imam Rabbani. In the fifteenth century, the Muslims in the Indian subcontinent have been infiltrated various superstitions, one of the Mughal Emperor Akbar's abandoning Islam in 1582 and established a new religion called "Din-i Ilahi." At that time, Imam Rabbani Mujaddid-e Alf-e Sani Shaykh Ahmad Sirhindi Faruqi (1564-1624) made a significant contribution to the Muslim umma. During the Imam Rabbani era, two misguided groups emerged in Sufism. A group introduced themselves as sharia followers, and the other group presented themselves as tariqa followers. He declared in a clear voice that both groups are in utter delusion and mentioned that shariatariqa are complementary to one another. One cannot fulfill the other. Therefore, those who reject one and reject the other are essentially denying an integral part of Islam. He was the first in the Indian subcontinent to reconcile sharia and tariqa. He used various methods to attract the country's administration to Islam. One of these is establishing good relations with the state's ruling responsible officials and educating them in Islam's actual teaching. He founded the Mujaddidi Sufi tariqa in the Indian subcontinent in the seventeenth decade. His principles revolutionized Islamic thought in the Indian subcontinent by abolishing the 'Din-i Ilahi' religion in the new faith introduced by the Mughal Emperor Akbar. At the same time, his principles caused a stir in the world of religious practice and thought. ${ }^{1}$ People were moved to read his writings and listen to his speeches. As a result of his relentless efforts, various superstitions were removed from Islam. He worked hard all his life to convert the Muslims of the Indian subcontinent to the Qur'ān and the Sunna. He was recognized in the Muslim world as Mujaddid-e Alf-e Sani, the reformer of the second millennium. He is best known for his opposition to antiIslamic activities during the reign of Mughal Emperor Akbar. ${ }^{2}$

To understand this subject, we had to do an excellent historical study of diverse literature. This study relied on content analyses from

\footnotetext{
1 Vahit Göktaş and Saeyd Rashed Hasan Chowdury, "Freedom of Religion, Faith and Religious Tolerance in Bangladesh: A Case Study on the Islamic Mysticism”, Disiplinlerarast Sosyal Bilimler Dergisi 5 (2019), 41-67.

2 Saeyd Rashed Hasan Chowdury, "Bangladeş'te Tasavvufun ve Tarikatların Değerlendirilmesi, Sosyal Gelişimleri ve Oynadıkları rol: Yirmi Birinci Yüzyılda bir vak’a Incelemesi” (Ankara: Ankara University, 2019), 7-18.
} 
trusted secondary sources. Content analysis, a rigorous review of relevant documents, includes books, credible newspaper articles. The magazines and web-based documents that have been written on Imam Rabbani have also been investigated. We have tried to give a brief description of the work that has been done in academia on Imam Rabbani in the present world. We have also tried to enrich our article with references from these pieces of literature. Afroz Ahmad Bisati, in his PhD thesis on "Imam Rabbani's Thought", described that Ahmad Sirhindi, a great Indian saint of the $17^{\text {th }}$ century who was also a religious reformist and renovator, had a revivalist mindset in line with the times. He was born in 1564 when Muslims passed through a crucial turn in their history in the subcontinent. Religious deviations impacted every segment of the Muslim community.

In contrast, the Sufis had misunderstood Sufism and its relationship with the sharia. Imam Rabbani Ahmad Faroq al-Sarhandi, who was well aware of the conditions and circumstances in which he found himself, elaborated on the various aspects of his thought accordingly. To make an ultimately accurate assessment of his view, one must understand him in the context of his time. His ideas are based on the Qur'ān, Sunna, and sane Sufi experience. ${ }^{3}$

Abdul Aziz and Siddiq Ahmad Khan, in their book Harrat Mujaddid Alfesani (Biography), mentioned that Sufism in the Indian subcontinent today comprises various hypocrites and followers who have strayed far from authentic Islam. ${ }^{4}$ Also, some groups have been associated with shirk. So, at present, the people of the Indian subcontinent should follow Imam Rabbani's thoughts. He formed a movement against Akbar's "Din-i Ilahi" and the false Sufis to get Islam's actual teachings. Suppose the real scholars of the subcontinent can also form such a movement now. In that case, the Muslims in the Indian subcontinent will get real Islam, and everyone can live in peace and happiness. ${ }^{5}$ Masud Alam Nodovi refers in his book of Upmobadeshe Islami Andoloner Itihas that when the religious strife and confusion created by Emperor Akbar went beyond the limits and the

3 Afroz Ahmad Bisati, Sherkh Ahmad Sirhindi's Thought and its Impact on The Development of Sufism (Srinagar: Shah-i-Hamdan Institute of Islamic Studies The University of Kashmir press, 2001), 237-239.

${ }^{4}$ Itzchak Weismann, "Indian Roots of Modern Islamic Revivalism", Journal of South Asian and Middle Eastern Studies 36, no. 4 (2013), 19-35.

5 A.F.M. Abdul Aziz and Siddique Ahmed Khan, Harrat Mujaddid Alfe Sani (Dhaka: Islamic Foundation Bangladesh, 2001), 16. 
government persecution of the pure Muslims continued, then Allah sent Imam Rabbani the grace to play the role of reformer in this part of the Indian subcontinent. He was the first to introduce true Sufism in this land of gods and goddess worship. ${ }^{6}$

A. F. M. Abu Bakar Siddique has recorded in his book Din-iIlabi of Mujaddid Alf Sani that Imam Rabbani was able to thwart the conspiracy of Emperor through his thoughts and efforts Akbar to destroy the Islamic way of life and culture in the Indian subcontinent. He also wrote against the hypocritical Sufis. He has mentioned all these things in his book Maktübät. This book still exists as the primary document of his reform movement. ${ }^{7}$ Mohammad Ruhul Amin, in his book titled Mujaddid-i Alfesani's Reform Movement, has described that Muslim society today is lost in all aspects. The turbulent times during the time of Imam Rabbani are also present in the Muslim world's personal, social, cultural, and political life. That is why the need for a comprehensive discussion of that successful reform movement led by Imam Rabbani is urgent today. ${ }^{8}$

By reviewing these pieces of literature, we have concluded that the present Muslims, especially in the Indian subcontinent, are divided into different groups and sects. In this case, if everyone can be influenced by the thoughts and philosophy of Imam Rabbani, then this conflict can be resolved.

\section{Imam Rabbani: Renowned Great Man of the Reform Movement}

During the Muslim Revolution in the Indian subcontinent in the fourteenth century, Imam Rabbani laid out some excellent strategies. One of them is to build good relations with the ruling ministers-bureaucrats and responsible officials of the state. Imam Rabbani tried to inculcate them in the correct teachings of Islam. Besides, he started calling Emperor Akbar towards Islam. However, He started his reform activities by building good relations with the influential quarters of the state. ${ }^{9}$

6 Masud Alam Nodovi, Upmohadeshe Islami Andoloner Itihas (Dhaka: Sotabdi Prokashoni, 2002), 12.

7 A. F. M. Abu Bakar Siddique, Din-i-Ilahi o Mujaddid Alfe Sani (r) (Dhaka: Islamic Foundation Bangladesh, 1991), 6.

8 Muhammad Ruhul Amin, Mujaddid-i Alfesani's Reform Movement (Dhaka: Islamic Foundation Bangladesh, 1984).

${ }^{9}$ Yohanan Friedmann and J. G. J. Ter Haar, "Follower and Heir of the Prophet: Shaykh Ahmad Sirhindī (1564-1624) as Mystic", Journal of the American Oriental Society 


\section{Din-i Ilahi Introduced by Emperor Akbar}

In discussing the reform activities of Imam Rabbani, one must understand Din-i Ilahi by Emperor Akbar. Mughal emperor Akbar is one of the most infamous characters in history. Of course, he also has success in various fields. However, the thing that has turned him into a villain of history is that he abandoned traditional Islam. ${ }^{10}$ In 1582 he started preaching a new religion called Din-i Ilahi. However, it is propagated that all faiths' functional aspects have been added to this new religion. Manazir Ahsan Gilani, a well-known Indian debater, thinks that Din-i Ilahi was a new Hinduism version. ${ }^{11}$ The main feature of this new religion was the adoration of the sun. In this new religion, the name of the sun has been pronounced as Jallat Kudratuhu. It was also the duty of this religion to make Hindus believe in reincarnation. The Jain saints greatly influenced emperor Akbar. ${ }^{12}$

According to Jainism, the king himself gave up eating meat. The king was also greatly influenced by the fire-worshippers. His order had always been to light a fire in front of the palace. Bells are received from Christians. In general, all religions, except Islam, seemed beautiful in the eyes of the king. Hinduism seemed the most beautiful in his eyes. Most of the elements of his new religion, 'Din-i Ilahi,' were adopted from Hinduism. ${ }^{13}$ The motto of Din-i Ilahi was Là iläha illa Allah Akbar Khalil Allah. The Emperor's followers also had to prostrate the king. ${ }^{14}$ At that time, Tajul Arefin, the head of the false Sufis in the Indian subcontinent, issued a fatwa saying that it was obligatory to prostrate before the king. This prostration is called 'Zamin Boch. 'He said it was compulsory to show respect to the king. He explained this by taking the actions of the corrupt Sufis of India as

114, no. 3 (1994), 460; Arthur F. Buehler, "Ahmad Sirhindī: A 21 ${ }^{\text {st }}$ Century Update", Der Islam: Journal of the History and Culture of the Middle East 86, no. 1 (2011), 122-141.

${ }^{10}$ Nodovi, Upmohadeshe Islami Andoloner Itihas, 14.

${ }^{11}$ Muhammad Akram Kha, Muslim Bonger Samajik Itihas (Oitijjo Prokashoni, Dhaka 2002), 161.

12 Siddique, Din-i-Ilahi, 11; Muzaffar Alam, "The Mughals, the Sufi Shaikhs and the Formation of the Akbari Dispensation", Modern Asian Studies 43, no. 1 (2009), 135174.

13 Aziz and Khan, Harrat Mujaddid, 148.

${ }^{14}$ Kha, Muslim Bonger Samajik Itihas, 162. 
evidence. ${ }^{15}$ Not only ordinary people but also eminent scholars were involved in this shirk. Interest and gambling were baläl in this new religion. ${ }^{16} \mathrm{~A}$ house was built for gambling at the court. Furthermore, gamblers were lent money at stake from the treasury. Drinking alcohol was also made haläl.

The king himself opened a bar near the court. Most of the scholars and muftis were forced to drink alcohol on Nowruz. ${ }^{17}$ In this religion, it was essential to cut the beard. The law of this religion was that young women should be forced to keep their faces open. Adultery was legalized by setting up prostitutes in various places outside the city. The Emperor forbade cow slaughter, and he issued a law that if anyone ate with the butcher, his hand would be cut off. Although his wife eats with the butcher, his fingers will be cut off. In this new religion, it was forbidden to eat cattle, camels, sheep, etc.

On the other hand, the meat of the tiger has the status of halal. Reading and knowing Arabic was declared a crime. In this new religion, the eating of cattle, camels, sheep, etc., was prohibited. Emperor Akbar levied the jizya tax on Hindus. Emperor Akbar used all his power to eradicate even the last traces of Islamic rule. As a result, within a few years, no bit of Islam remained in any government. Praying in the mosque was forbidden. The madrasa was destroyed. The primary purpose of Din-i Ilahi was to oppose Islam in all respects. Most of the scholars were forced to leave the country. Eventually, during Emperor Akbar's reign, a situation arose in which the Sunni Muslims became enraged. The people of all other communities except the Sunni Muslims were very dear to the Emperor. Due to the divinity of this religion, non-Muslims were incredibly honored, while Muslims were much humiliated. At the same time, Muslims began to accept the oppression of non-Muslims in every case by following the Islamic rules. ${ }^{18}$

\footnotetext{
${ }^{15}$ Siddique, Din-i-Ilabi, 29.

${ }^{16}$ Kaler Kontho, Mujaddede Alfe Sani (rh): Songskar Andoloner Kirtiman Mohapurush (Dhaka: Daily Kaler Kantho Newspaper, 2014), 7.

17 Muhammad Aslam, Din llabi aur Is Ka Pasmanzar (Delhi: Besturdubooks, 1969), 38.

18 Ahmad Aziz, Hind wa Pak Main Islami Culture (Delhi: Islamic Cultural Society, 1991), 28.
} 


\section{Imam Rabbani Protesting against the Hypocrites}

Imam Rabbani tried to resist the anti-Islamic activities that started during the reign of Akbari. Emperor Akbar died in October 1605 at the age of 70 after a long reign of 46 years. The last ten years of his life were not pleasant for him. He spent his days in various adversities, disasters, and tragic situations. He introduced that Din-i Ilahi misled ordinary Muslims in the religion. ${ }^{19}$ Imam Rabbani took multiple steps in the whole case with foresight. In this regard, Maulana Mohammad Akram Khan was deeply saddened by all the plan's miserable failure. He had been trying to implement in the last ten years of Emperor Akbar's life. ${ }^{20}$ In his life, Akbar was genuinely remorseful for his extreme opposition to Islam. Western historians, however, disagree. According to them, Akbar's legend, with his sharp and sound judgmental intellect, deliberately rejected the superstition, retook it, and died is irrelevant. Superstition here means all these historical Islam. However, the funny thing is that they did not see any sign of superstition in Akbar's puppet worship, material worship, and his trinity belief. ${ }^{21}$

After that, when Jahangir has taken power, he became active again in launching all the anti-Islamic activities and superstitions introduced by his father, Akbar. Besides, he did not skimp on providing commercial facilities to the English. As a result of his shortsightedness, the English set up mills in various places. ${ }^{22}$ Moreover, the English had a chance to make an impact. The British's arrival in the Indian subcontinent was one of the main reasons for the Mughals' downfall. ${ }^{23}$ Nurjahan, the wife of Emperor Jahangir, was able to exert influence in the kingdom. The situation took such a shape that the rule of the empire practically passed into the hands of Queen Nurjahan. Nurjahan was a staunch Shia. Rafezi Shia influenced Nurjahan. ${ }^{24}$ Many historians believe that she dreamed of establishing a

${ }^{19}$ Muhammad Aslam, "Jehangir and Hadhrat Sheikh Ahmad Sirhindi", Journal of Asiatic Society of Pakistan (June 1, 1965).

${ }^{20}$ Siddique, Din-i-Ilahi, 16.

${ }^{21}$ Akram Kha, Muslim Bonger Samajik Itihas, 162.

${ }^{22}$ Muhammad Abdul Haq Ansari, Sufism and Shari'ah (London: Islamic Society, 1986), 88.

23 Arthur F. Buehler, "The Naqshabandiyya in Timūrid India: the Central Asian Legacy", Journal of Islamic Studies 7, no. 2 (1996), 208-288; KS Siddiqui, Mojaddedde Alfesani (Rah.) and Emperor Jahangir (Dhaka: Dailyinqilab Newspaper, 2016), 8.

${ }^{24}$ Akram Kha, Muslim Bonger Samajite Itihas, 164. 
Shiite state. As a result, the influence of Shia ulama, muftis, and advisers increased in the court. On the other hand, the situation was such that shirk and idol worship practices began to prevail among Muslims all over the country. ${ }^{25}$

Furthermore, all sorts of superstitions are spreading everywhere. Moreover, a new slogan is being uttered that 'Sharia is a separate thing, and tariqa is different. All in all, this era of Emperor Jahangir was the era of the extreme decline of Islam. In such a situation, Imam Rabbani started writing various letters to the influential people of the state. Imam Rabbani also influenced the senior officials of the state. Even in the end, he influenced Emperor Jahangir. ${ }^{26}$ However, the brutal and torturous treatment meted out by Emperor Jahangir to Imam Rabbani was a reprehensible chapter in history. ${ }^{27}$

\section{Propaganda against Imam Rabbani}

The Rāfidah Shiites started spreading various lies and propaganda against Imam Rabbani. As a ploy, they changed and distorted the letters of Imam Rabbani's Maktübät and presented them to the Emperor. Because of Nurjahan, the Rafizi Shiites hoped that they would establish a Shiite regime. ${ }^{28}$ However, because of Imam Rabbani, their hopes were dashed. So, they all united against Imam Rabbani and made a deep-rooted conspiracy. As a result of this propaganda, even influential scholars like Shaykh Abdul Haq Mohadded Dehlavi were also influenced. The Emperor, of course, created a turbulent situation in the whole of India.

The conspirators cut and distorted Imam Rabbani's letters to Emperor Jahangir. For example, the interpretation of a letter to the Emperor is interpreted so that Imam Rabbani considers himself superior to Abū Bakr al-Siddīq. However, propaganda became so severe that when Emperor Jahangir summoned Imam Rabbani to his palace, he appeared. When Emperor Jahangir asked Imam Rabbani about all these things, and he gave a perfect answer. The

\footnotetext{
25 Aziz and Khan, Haqrat Mujaddid, 175.

${ }^{26}$ Denison Ross and Eileen Power, Akbar and the Jesuits, trans. C.H. Payne (Delhi: De Gruyter, 1979), 98.

27 M.L. Roychoudhary, Din-i-Ilabi (The Religion of Akbar) (Delhi: Tezpur University, 1985), 76.

${ }^{28}$ Akram Kha, Muslim Bonger Samajik Itihas, 165.
} 
misconceptions that Emperor Jahangir had given about Imam Rabbani also came to an end.

However, the conspiratorial circle began to convince the Emperor again that Imam Rabbani was a traitor. All the ulama have unanimously issued a fatwa saying that it is permissible to prostrate to the Emperor in tajimi (honor). However, Imam Rabbani, in his Maktübät, has opposed this sharia fatwa. Emperor Jahangir ordered Imam Rabbani to prostrate. Imam Rabbani vehemently refused to follow this instruction and said that according to the provisions of the Qur'ān, prostration is for Allah alone. ${ }^{29}$ Hearing this, Emperor Jahangir got angry. Moreover, he ordered Imam Rabbani to be sent to prison. Moreover, for a long time, he was in jail.

By going to jail, he accelerated his reform movement. He began to spread the message of Islam among the prisoners. He began to explain to them the correct thoughts and ideas of Islam. Impressed by the beauty of his character, the prisoners started to pray. Thus, a whole year and two months passed. ${ }^{30}$ Emperor Jahangir learned that in Imam Rabbani, the ordinary people began to become the saints of Allah. Upon receiving this news, a significant change took place in the background of Emperor Jahangir. He ordered the release of Imam Rabbani and brought him to the president's palace. ${ }^{31}$

\section{The Reform Activities of Imam Rabbani}

Emperor Jahangir requested Imam Rabbani to give him some time in the royal court. Moreover, he worked to correct the armies. Imam Rabbani accepted the offer. Imam Rabbani took advantage of this opportunity to present Islam's beauty in front of everyone in the president's palace every day. Emperor Jahangir, Shah Jahan, influential ministers, began to be influenced by his words. His genuine compassion for the religion, immense love for Islam, and arrogance towards state power fascinated everyone. The fear of doubt began to disappear from the heart of Emperor Jahangir. Everyone in the president's palace, including the Emperor, became his devotee. Imam Rabbani stayed at the Emperor's castle for three and a half years. A

\footnotetext{
29 Nowroze Cooverji Mehta, The Religious Policy of Akbar (Delhi: Otichco Prokahsoni, 1966), 87; Arthur Buehler, "Sharī'at and 'Ulamā in Ahmad Sirhindī's Collected Letters", Die Welt des Islams 43, no. 3 (2003), 309-310.

${ }^{30}$ Aziz and Khan, Harrat Mujaddid, 148.

${ }^{31}$ Amin, Mujaddid-i Alfesani's Reform Movement, 129.
} 
radical change is observed in everyone, including the Emperor, and everyone regrets his past sins. Seizing the opportunity, he proposed to Emperor Jahangir to implement the seven-point demand.

Moreover, he made seven demands to the Emperor:

1. It is necessary to abolish the evil practices of prostration of the Emperor.

2. The prohibition on slaughtering cows should be lifted.

3. The Emperor and his courtiers have to complete the prayers with the first takbir.

4. The Sharia Department should be re-established, and Qazi's post should be re-established.

5. All kinds of superstitious and anti-Islamic activities that prevail in society must stop.

6. It is necessary to renovate the destroyed mosques and organize prayers with them.

7. All of Akbar's anti-Islamic laws must be declared null and void. ${ }^{32}$

The Emperor accepted his demands. Moreover, it issued a directive to this effect. In the Indian subcontinent removing a new religion like Din-i Ilahi as opposed to Islam is one of the outstanding achievements of Imam Rabbani's life. ${ }^{33}$

He presented his perceptions, decisions orally and in written form to the nation in easy-to-understand language. ${ }^{34}$ He thought that the king's relationship with the empire was like the relationship between the body and the mind. ${ }^{35}$ If the reason is correct, then the body is also suitable. If the mind goes wrong, then the body goes astray. So, the king's correction is the correction of the empire. The destruction of the king is the name of the destruction of the whole kingdom. For this reason, he preferred to change the attitude of the ruler rather than change the rules. However, he took up various programs, and that is: a). Correction of private eminent persons; b). Amendment of high-ranking government bureaucrats; c). Amendment of the Emperor; and d). Correction of courtly scholars. ${ }^{36}$

\footnotetext{
${ }^{32}$ Mamunur Rashid, Biography of Harrat Mojadded Alfesani (Dhaka: Dharmapurdarbar, 2018), 1.

${ }^{33}$ Nodovi, Upmobadeshe Islami, 14.

${ }^{34}$ William Foster, Early Travels in India (United Kingdom: Oxford University Press, 1921), 27.

${ }^{35}$ Aziz and Khan, Harrat Mujaddid, 75.

${ }^{36}$ Siddique, Din-i-Ilabi, 40.
} 
Imam Rabbani has been able to bring about a change in the thinking and attitudes, morals, and customs of the public and private, military and civilian people in the Indian subcontinent. ${ }^{37}$ The issues that he has tried to reform are mentioned below:

First, Imam Rabbani should pay attention to the correction of administrators and public servants. If Islam's appeal can be raised in the heart of this class of persons, the entire nation is inclined towards Islam. His method was primarily successful.

Second, Imam Rabbani first presented the correct form of religion to the people, united those who had adopted it, and sought to correct their character, i.e., faith, creed, and conduct.

Third, Imam Rabbani did not openly oppose the bid'a. He ordered him to follow the Prophet's Sunna and said that this was the only way to success and happiness. His statement was the only goal of human creation to realize all servants' rights and keep Allah's attention. This situation will be created when people completely and secretly follow the great leader's ideals. ${ }^{38}$

Man's worldly peace and the liberation of the hereafter depend on following the Prophet's ideals. When a Muslim fully follows the Prophet's example, he becomes a faithful servant of Allah. Then people become successful in the lovers of Allah. The person who achieved this success was promoted to the same rank as the prophets of Israel. ${ }^{39}$

Forth, Imam Rabbani felt that the weakness, selfishness, and self-contradiction of a class of dishonest scholars are mainly responsible for the disasters that Islam faces in the present and imminent disasters. Therefore, he did not hesitate to expose and sharply criticize misleading scholars about Islam. Moreover, he called them to Islam in various ways.

Fifth, Imam Rabbani further felt that most contemporary Sufi saints were influenced by Vedanta and Hindu philosophy. A large part of them were supporters of the doctrine of pantheism. Imam Rabbani vehemently opposes all these ignorant Sufi saints and their misguided

\footnotetext{
${ }^{37}$ Amin, Mujaddid-i Alfesani's Reform Movement, 135.

38 Mohammad Israfil Hossain, Mujaddide Alfe Sunny Rabimabullab Talks about Life (Dhaka: Alqur'anerpath, 2019), 11.

39 Allama Muhammad Iqbal, Reconstruction of Religious Thought in Islam (Delhi: Adam Publishers, 2001), 29.
} 
beliefs and principles. His contribution elevated him to the pinnacle of knowledge and intellectual advancement in India at that time.

Sixth, for a long time, a class of less-educated Pir had the habit that whenever they were attracted to a bid'a, they would try to keep it as bid'a hasana. Imam Rabbani was very critical of it, and he thought there was no such thing as hasana in bid'a.

Seventh, during the reign of King Akbar, the influence of the Rāfiḍah Shiites spread the Mughal Empire for several reasons. It remained intact even during the reign of Jahangir. Imam Rabbani made two attempts to eradicate the fitna of the Rāfidahs: 1). Imam Rabbani defeated the Rāfiḍah ulama by openly arguing and negotiating with them, thus halting the Răfidah influence; and 2). In his book Maktübät, he tries to solve the problems between the principles and beliefs of the Imamiyya school. ${ }^{40}$

Eighth, after all, Imam Rabbani is the first person in the Indian subcontinent to criticize the evil aspects of scholars, starting with the head of state. Moreover, they called everyone to spiritual Islam. He has repeatedly stated this in his Maktübät.

\section{Doctrines of Imam Rabbani Shaykh Ahmad Sirhindi}

With his wisdom and determination, Imam Rabbani devoted himself to reform, according to Islam in the Indian subcontinent. He tried to get rid of Islam by introducing a lot of heresy and disbelief. Imam Rabbani first attempted to purify the Emperor. He thought that the king needed to be reformed. Because the Emperor is like the soul, and the people are like the body. If the disease of the soul is removed, the body will also be free of the illness. However, the ministers need to be consulted before the king can be discussed. Imam Rabbani focused on that. When Imam Rabbani diagnosed the cause of the disease, he saw that most Muslims in India had turned away from Islam. ${ }^{41}$

Moreover, they have followed the fabricated Islam. The scholars of the nation were then misguided and endangered by the greed of worldliness. At that time, he was vocal about various issues through Maktübät. Imam Rabbani at that time made multiple doctrines to solve numerous problems, and that is:

\footnotetext{
${ }^{40}$ Nodovi, Upmohadeshe Islami, 14.

41 Abdul Shakoor Faruqi, Imam Rabbani: al-Furqan-Mujddid Alf Thani (Lucknow: Academia, 1961), 87.
} 


\section{Everyone Must Return to the Islam}

According to Imam Rabbani, no matter how big a tree is, it must be connected to the root. Only then will it draw juice/vitality from the basis and stay fresh from sunlight and nitrogen from space and nature. A tree in its excellent and original position never gets anything harmful from the sky and nature. That is how a tree survives and is adorned with fruit flowers. However, no matter how much food a tree disconnects from the root, its death is inevitable.

The core of Islam and Muslims is the Qur'ān and the Sunna of the Prophet. Suppose the origin of Islam has a close connection with the tree. In that case, it will extract juice/vital energy from this root and, if necessary, will take essential participation from other doctrines of the world, giving up unnecessary parts. ${ }^{42}$ In this way, he will keep himself alive, fresh, and complete. Islam is the role model of Muslims. Their individual, collective, national, and state ideologies and activities depend on this Islamic ideology. If they adhere to this ideal, they will survive as the best nation in the world. They will lead the world; they will rule. However, if they move away from the original, they will no longer survive as a living nation. ${ }^{43}$ In the world, they will become an inferior, oppressed, and humiliated country. Fuel, like wood, will be used for other purposes. It will not be of any use to one's nation.

\section{Founder of Wahdat al-Shuhūd Theory}

Ibn 'Arabī's philosophy is Waḅdat al-Wujūd or the Oneness of Being. Ibn 'Arabi expressed this doctrine as follows: The existence of the whole creation is the very existence of Allah. Here he refers to the "Wahdat al-Wujūd," that is, the unity and oneness of the Creator's presence and the creation, as Ainiyat or Hubbuta. ${ }^{44}$ Persian poets Fariduddin Attar, Sadruddin, Nablusi, and others have highlighted and explained this Wabdat al-Wujūd doctrine of Ibn 'Arabī. Nablusi explains that Allah is the only existent being. From this perspective, He does not exist by all other beings, but He lives in his being.

\footnotetext{
42 Sheikh Ahmad Sirhindi, Risäla Tablïliyya (Arabic text with Urdu tr., Dr. Gh. Mustafa Khan) (Karachi: Iqbal Review, 1965), 12.

43 Sheikh Ahmad Sirhindi, Sharb-i-Rubäiryat (Persian text with Urdu tr., Dr. Gh. Mustafa Khan) (Karachi: Iqbal Review, 1966).

44 A.E. Affifi, The Mystical Pbilosopby of Mubyiddin ibn al-'Arabi (UK: Cambridge University Press, 1939), 28; Abdul Haq Ansari, "Ibn 'Arabī: the Doctrine of Wabdat al-Wujüd', Islamic Studies 38, no. 2 (1999).
} 
Regarding the correct interpretation of the word "Waḅdat alWujūd," the scholars have said that it does not mean the actual and literal meaning. ${ }^{45}$ Instead, it is a kind of metaphor meaning. In this metaphorical sense, everything that exists has been described as nonexistent in the presence of Allah. In such a figurative sense, everything that exists has been described as non-existent in the sight of Allah. Moreover, this is the term Wabdat al-Wujūd.

Imam Rabbani criticized the Wabdat al-Wujūd theory. In addition to this term, Imam Rabbani has used a new name. That is the "Waḅdat al-Shubūd theory" ${ }^{46}$ Wahdat al-Shubüd refers to the relationship of the individual entity with the Absolute Being. To attain nearness to Allah means gaining His mercy and love through Waḅdat al-Shubüd and gaining greater knowledge about Allah. ${ }^{47}$ Besides, the essence of $W$ abdat al-Shubüd is that in all existing things, shubüd or vision will be focused on only one entity. Imam Rabbani has termed it very safe to use the term Wabdat al-Shubuid instead of $W$ abdat alWujüd. ${ }^{48}$ Ignorant Sufis and so-called philosophers can mislead the Ummah from Islam without understanding the necessary interpretation of $W$ aḅdat al-Wujüd. Moreover, the term "Waḅdat alShubüd" is self-explanatory, where it does not deny others' existence. ${ }^{49}$

According to Imam Rabbani, during Sufis, tawhid appears in two types, tawhid al-wujüd and tawhid al-shubiud. At the level of tawhid alwijüd, the devout "knows existence as one" and believes that way. $\mathrm{He}$ knows none other than Allah and accepts its manifestations as illusions. On the other hand, at the level of tawhid al-shubüd (wahdat alshubüd), the devout sees existence as one. He sees only the existence of Allah but does not deny that there are other beings besides him. ${ }^{50}$

\footnotetext{
${ }^{45}$ Rom Landau, The Philosophy of Ibn al-'Arabi (London: Academy, 1959), 67.

${ }^{46}$ Cavit Sunar, Vabdet-i Şubūd-V abdet-i V ücūd Mes'elesi (Ankara: Anadolu Aydinlanma Vakfi Yay, 1960), 17; M. Abdul Haq Ansari, "The Life and Mission of Shaykh Ahmad Sirhindî”, Islamic Culture 59, no. 2 (1985), 95-116.

${ }^{47}$ Abu Sa'id Nur al-Din, Wahdat al-Wujud and Falsafa Khudi (Karachi: Iqbal Review, 1962).

48 Ebu'l-Alā Afifi, Mubyiddin İbn Arabìnin Tasavvuf Felsefesi, trans. Mehmet Dağ (Ankara: AÜIFY, 1975).

${ }^{49}$ Mir Valiuddin, "Reconciliation between Ibn al-'Arabi's Wabdat -i- Wujud and the Mujaddid's Wabdat-i-Shubud', Islamic Culture 25, no. 1-4 (1951).

${ }^{50}$ Necdet Tosun, Imam-ı Rabbani Abmed Sirbindi (İstanbul: Insan Yayınları, 2005), 98.
} 
Imam Rabbani described these two concepts of wabdat (unity) with the example of the sun and the stars: When the sun rises during the day, the stars become invisible. When someone says, 'there are no stars in the sky, there is only The Sun' and believes this is an example of the state of Wabdat al-Wujüd, it is a close ilm al-yaqin (order of knowledge). According to Imam Rabbani, Waḥdat al-Wujüd is an illusion of perception. I can't see anything other than the sun in the sky, but this does not mean that there are no stars, there are stars, but the person who thinks that they have become invisible due to the intense light of the sun is an example of the people of $W$ ahdat alShubüd, it is a close order of 'ilm al-yaqin. Suppose this person's vision becomes more substantial and can see the sun and stars separately. In that case, this is the rank of haqq al-yaqin (abadiyya), which is of a higher order than the other two. ${ }^{51}$

Therefore, there are three groups of Sufis regarding existence: first, those who know the existence as one (people of $W$ ahdat alWujud $)$, second, those who see the existence as one but believe that it is two (people of Wabdat al-Shubūd), and third, those who see existence as two (those who reach abadiyya level). According to Imam Rabbani, the highest rank to be contacted for a devout is the third. ${ }^{52}$

By introducing this $W$ abdat al-Shubüd theory, Imam Rabbani has gained a special status in the Indian subcontinent and the entire Islamic thought world's history.

\section{Imamate}

According to Imam Rabbani, many awliyas are dead until now. Many of them even achieve the Chogra maqaim in the maqäm of Sufism. However, the Sufis could not pass through the Cobra at Belayat until now. Only the Prophet's companions were able to reach the position of Cobra in Belay, Ulia in Belay, and Nabuwat in Kamal. Thousands of years later, Imam Rabbani was able to overcome the maqam. He thinks that the awliya a' of the last century did not reach kamalat alnabumwa because of their opposition to some aspects of sharia. It is noteworthy that Imam Rabbani, in his Maktübät, described the maqāms of Khiläfa, Imāma, Chabekiyat, Khaleshiyat, Mukhlechiyat, Rezaiyat, and Qayumiyat. ${ }^{53}$

\footnotetext{
51 Ibid., 99.

52 Ibid., 99.

${ }^{53}$ Aziz and Khan, Hazrat Mujaddid, 138.
} 
According to him, the discussion of the caliphate and imamate was not a fundamental religious issue for Ahl al-Sunna wa al-Jamā'a. It was not a matter of creed; the divisive within Islam had made many exaggerations and errors in this regard. ${ }^{54} \mathrm{He}$ has incorporated this subject in Tlm al-Kalam (belief) and made it a reality. After Prophet Muhammad, Abū Bakr al-Ṣiddīq was elected Caliph. Then 'Umar bin al-Khațậa, 'Uthmān bin 'Affān, and finally, 'Alī bin Abī Ṭālib were elected Caliphs. They became the best according to the order of their caliphate. Imam Rabbani further thought that Imamate belonged to the branch of religion. However, it is not a fundamental issue of the sharia. If the subject of Imamate was an essential subject of religion and sharia, and then the Qur'ān would specify who would be the Caliph. ${ }^{55}$

And the Prophet used to choose who would be the Caliph after him at his death. Thus, it proves that the issue of Imamate is not an essential matter of religion. The point of Imamate is as worthless as the essentials of faith. Imam Rabbani mentioned a need to liberate Islam from the fitna (violence) of those who want to create division within Islam on this Imamate issue.

\section{Tajdid (Renewal of The Religion)}

Tajdid is an Arabic term that refers to reviving the connection between religion and life as a structural element in Islamic thought. "At the beginning of every century, Allah sends someone who renews his religion to this umma" ${ }^{56}$ It is claimed that the Imam al-Shāfi 'is followers generally used this Hadith to indicate that the regenerator of the second Hijri century was Imam al-Shāfí⿴\zh11 (d.204 / 819). A study on this subject shows that the mujaddids in its historical course also claimed from the Egyptian region, where the Shāfi' $\overline{1}$ madhbab is widespread. $^{57}$

54 Muhammad Hashim Kishmi, Zubdat al-Maqāmāt (Kanpur: Aligarh Muslim University, 1980), 27.

55 İbrahim Ethem Bilgin, Devrimci Süfì Haraketleri ve İmam-i Rabbānì (İstanbul: Kültür Basın Yayın Birliği, 1989).

56 Abū Dāwud Sulaymān b. al-Ash'ath b. Ishạā al-Azdī al-Sijistānī, Sunan Abì Dāwud, "Kitāb al-Malāhim", Vol. 4 (Egypt: Maktaba Sharika and Maktabat al-Muṣtafā, 1952), 480.

57 Ethem Cebeceoğlu, Tasavvuf Taribi: Imam-i Rabbānì ve Vabdet-i Şubūd Anlayıșı (Ankara: Ankara Üniversitesi Uzak Tan Eğitim Yayınları, 2013), 332. For a discussion on the genealogy of the the concept of tajdid, see John O. Voll, "Renewal 
Imam Rabbani says that he is a mujaddid with a closed implication. Imam Rabbani says that the truths of the world are men. According to him, these sciences appeared a thousand years later, though no one had mentioned it before. He says, "O son," on this subject, "This is such a time that if the cruelty/darkness increased in this way in the ancient nations, a prophet would be sent, and he would revive a new religion. In this ummah, which is the last of the ummahs, its Prophet is also the last, and his scholars are at the level of the prophets of the Israelites. The existence of scholars replaces the presence of prophets. For this reason, at the beginning of every century, a mujaddid is appointed by the scholars of this umma to revive sharia in Islam.

At the beginning of our article, we explained how Imam Rabbani was born in a dark period. As Imam Rabbani said, there was a great need for a revival and reform on such a ground, and it was inevitable that the learned scholars undertook this task. Abdulhakim Siyalkoti was the first person to give him the title Mujaddid-e Alf-e Sani. Later, Shah Waliullah Dehlawi and Shah Abdul Aziz Muhaddith Dehlavi gave him the same title. Then this was accepted as a consensus among scholars. ${ }^{58}$

However, there is a significant difference between tajdid and tajaddud. The works carried out by Imam-i Rabbani are not tajaddud but tajdid. Tajaddud involves giving a new form to religion as a concept, tajdid; it means removing the elements of polytheism with superstitious ideas and behaviors and converting them into their original mixed with Islam and harm the essence. ${ }^{59}$ In an environment where bid'a were widespread and perverted beliefs were popular among Muslims, a radical movement was needed, which we described as a return to the essence. Thus, Imam Rabbani fulfilled this mission in many ways in India at that time, with the works he wrote, letters and the caliphs of tariqa he raised. He made great efforts to bring the madrasah and dervish lodge together in a balance, fought against bid'as, and strengthened the middle way called Ahl al-Sunna wa alJamā'a.

and Reform in Islamic History: Tajdid and Islah," Voices of Resurgent Islam (1983), 32 47.

58 Ibid., 333.

${ }^{59}$ Ibid. 


\section{Coordinating between Sharia, Tariqa, and Haqiqa}

In the time of Imam Rabbani, two erroneous groups emerged. One group began to identify themselves as sharia, and the other group as tariqa. The Shariati group claimed that Islam was only a collection of external acts, such as prayers, fasting, Haji, etc. There is no place for self-purification in this group. Furthermore, the Tariqati group claimed that Islam was only the sum of the Bateni period. The external period is useless there in this group. ${ }^{60}$ Therefore, just as the Shariati group did not give importance to the path of self-purification, the Tariqati group did not provide any value to prayers and fasting. Imam Rabbani, realizing the error and futility of both groups, became a defense against both groups. ${ }^{61}$

He declared in various letters and speeches that both groups were in extreme error. Because sharia and tariqa complement each other, it is impossible to fulfill one without the other. ${ }^{62}$ So those who cling to one and reject the other are denying an integral part of Islam. Furthermore, the necessity of capturing the sunna from its various letters is also clearly inferred from the horrors of bid' $a$. The sharia has three parts, and that is knowledge (ilm), action ('amal), and concentration or devotion (ikhläs). Until these three came together, there was no sharia. When the sharia was proved and implemented in a country, the people gained the pleasure of Allah. The key to all happiness in this world and the hereafter is the sharia. Tariqa and baqiqa (spirituality) are the characteristics and qualities of Sufis. However, these two things are the third part of the sharia. That is, it acts as a special helper of the sharia for the perfection of Islam. The fulfillment of the sharia is the sole purpose of tariqa and haqiqa. The combination of sharia and tariqa is a colorful chapter in his life.

\section{The Relationship between Man and Allah}

Imam Rabbani thinks that man's meaning is the soul, and Allah has created this soul. The relationship between man and Allah is like

\footnotetext{
${ }^{60}$ Hazrat Mujaddede Alfe Sani, Maarife Ladunniya (Narayangonj: Mujaddediya Kutubkhana, 2012), 53.

${ }^{61}$ Rejbi, Tajillate Alfe Sani, 21.

${ }^{62}$ Siddique, Din-i-Ilabi, 62.
} 
'abd (worshipper) and ma'būd (worship). 'Ubüdiyya (slavery) means that man should change his whole life according to the will of Allah. ${ }^{63}$

Moreover, only its orders and prohibitions should be obeyed because that is the command of Allah. There is another relationship between man and Allah, and that is: rif $a$ at. The word rif'at is conjugated form of the Arabic verb rufi'a in the meaning "lifted", "exalted", "joyous". The word of rif" at in Sufism tradition is used to mean to be imbued with the character of Allah. When a person transcends fan $\bar{a}$, stage and ascends to baq a' stage, he becomes a character of Allah. In this context, Allah said, "Be colored in the color of Allah; who can be a better color than His color?"

Allah is the guide who enlightens people about his existence through his Prophet. He is Aḷad or one, and he has no partner, is the only divine being. According to Imam Rabbani, Sufism is about helping people realize their purpose. Man is a servant of Allah, and the pursuit of his life is to serve Allah. Sufism is about assisting people in learning profoundly and intensely that he is a servant of Allah, nothing more. Sufism is about helping a person to be a faithful and perfect servant of Allah. Sufism is the adherents of sharia, tariqa, and haqiqa. The primary sources of this trilogy are the Qur'ān, Sunna, Ijma $\bar{a}^{-}$of mujtahids, and Qiyas. The purpose of the Sufi sulük is to believe in the aḅkam al-shari' $a$ and try to make it easier. ${ }^{64}$

\section{Controversy in Undergoing $\mathrm{Bid}^{\mathbf{6}} \mathbf{a}$}

He thought that if someone invents or adds something new in Islam, which is not in Islam, it is Bid'ah. In this regard, he mentioned that the last verse of the Qur'ann was revealed during the Farewell Hajj speech of the Prophet. As Allah says, I have perfected the religion for you today and completed My blessings upon you. Furthermore, I have chosen Islam for you as a religion. According to Imam Rabbani, an entire object could not have the slightest space for an external item. If there is a space in a thing, it is not complete, and it is incomplete. Besides, suppose that water comes in from outside in a full glass of water. In that case, the original water will be released, and the remaining water will be full of water. He added that Islam is a

63 Burhan Ahmad Faruqi, The Mujaddid's Conception of Tawhid (Delhi: Nabu Press, 1977), 32.

${ }^{64}$ Ethem Cebecioğlu, İmam-i Rabbani Hareketi ve Tesirleri (İstanbul: Erkam Yayınlar1, 1999), 21. 
fulfilling way of life. ${ }^{65}$ There is no place in Islam for anything invented other than the Book of Allah and the Prophet's Hadith. If anything incompatible with the Qur'ān and Sunna is introduced into Islam, it will be a complete innovation. Moreover, it will fall onto the stage of shirk and kufr.

Some of the jurists have divided bid'a into two parts. One of them is bid'a hasana (good bid'a), and the other is bid'a sayyia (bad bid'a). Imam Rabbani has rejected the division of hasana and sayyia in the bid'a. He mentioned that all innovations would lead to darkness. ${ }^{66}$ In this context, he has mentioned three hadiths.

1. If someone invents something new in Islam, which is not in it (Islam), it is abandoned. ${ }^{67}$

2. The Prophet said: You must follow my ideas and the ideals of alKhulafā' al-Rāshidūn. It will stand, and no action can be taken in addition to that. Because every newly invented act is bid'a, and every bid'a is misguidance and error. ${ }^{68}$

3. According to the Prophet Muhammad, if a nation invents innovation in its Islam, Allah will snatch from them a similar Sunna. So, this Sunna will not return to them before the Day of Resurrection. ${ }^{6}$

According to Imam Rabbani, all the deeds of the Prophet Muhammad were of two kinds: included in the stages of worship and had in practice. He thought that bid'a has nothing to do with qiyās and ijtihäd in Islam in this context. Qiyass and ijtibäd reveal the purpose and meaning of the Qur'ān and Hadīth alone. Qiyàs and ijtihäd do not discuss any additional provisions outside the Qur'ān and Hadīth.

\section{Hypocritical Prism in the Sufism}

There are many hypocritical Pir in the Indian subcontinent, where they pushed people away from Islam. Imam Rabbani mentioned that by hypocrites Prism, the caliphs of Allah become the

\footnotetext{
${ }^{65}$ Siddique, Din-i-Ilabi, 55.

${ }^{66}$ Arthur F. Buehler, Revealed Grace: The Juristic Sufism of Ahmad Sirbindi (1564-1624) (Louisville, KY: Fons Vitae, 2011); Kabir Khan, "A Short Bibliography of Shaykh Ahmad Sirhindi”, The Muslim World Book Review 12, no. 2 (1992).

${ }^{67}$ Abū 'Abd Allāh Muhammad b. Ismāōì al-Bukhārī, Saḥị̣ al-Bukhārì, Hadīth No. 2697 (Beirut: Dār al-Fikr, 2003).

${ }^{68}$ Ibid., Hadīth No. 5769.

${ }^{69}$ Bisati, Sherkh Ahmad Sirbundi's Thought, 156-167.
} 
caliphs of man. Tariqa is separated from Sharia. If not under the sharia, any tariqa is a manifest error. The general people go astray by following the Pir instead of following the Prophet.

Apart from this, his reforms are also memorable in the case of Sufism. He called for an authentic Islamic way of life by eradicating shirk, bid'a, kufr, etc. The gist of Imam Rabbani's statement about Sufism is that through the misguided Sufism, the tremendous revolutionary Muslims become meditators, great yogis, or monks. The Lions, the king of the forest, become domesticated cats. As a result of the infiltration of the above harmful doctrines in Islam, most of the Muslims of India lost their faith and practice during Emperor Akbar's reign. Furthermore, they went astray. That is why during the reign of Emperor Akbar, the Pir-Sufi Bedatis of India did not protest Akbar's anti-Islamic misdeeds and allied with Akbar to wipe out the right Islamists. $^{71}$

He thought, stay away from the contact of three people, among others: the scholar is neglecting his responsibilities, unlawful saints, and stupid Sufi. He further said that a person is seated in the seat of a spiritual initiator. If he does not follow the Prophet's Sunna, people should stay away from him because he is a thief in disguise and a Devil friend.

\section{Dhikr: The Remembrance of Allah}

There are two main types of dhiker (remembrances) in the Mujaddidiyya branch of Naqshbandiyya, which Imam Rabbani Ahmad Sirhindi founded: first, to repeat the remembrance of the name, i.e., the name of "Allah", a certain number of times; second, to repeat the word of al-nafy wa al-ithbät, that is, "Là ilāha illā Allah", a certain number of repetitions. ${ }^{72}$

According to Imam Rabbani, the remembrance of ism al-dhät (Allah) is more related to "temptation",", and al-nafy wa al-ithbät (Là iläha illa Allab) dbikr is related to sulük. The Naqshbandi's first

\footnotetext{
${ }^{70}$ Nodovi, Upmohadeshe Islami, 14.

${ }^{71}$ Siddique, Din-i-Ilabi, 19.

${ }^{72}$ Necdet Tosun, “İmām-i Rabbānī (K.S.)'nin Tasavvufĩ Görüşleri Tasavvuf Yoluna Giriş Ve Zikir", Somuncu Baba Dergisi 239 (2009); Sajida Alfi, "The Naqshbandi Mujaddidi Sufi Order's Ascendancy in Central Asia through the Eyes of its Own Masters and Disciples (17 th to $19^{\text {th }}$ Century)", in Todd Lawson (ed.), Reason and Interpretation in Islam: Theology, Philosophy, and Mysticism in Muslim Thought (London: I. B. Tauris, 2005), 407-417.
} 
mention the name "Allah". After reaching a particular maturity, they go to the chant "Lā ilāha illā Allah". Therefore, in this sect, the temptation (lure) comes before sulük..$^{73}$

There is no dhikr in Naqshabandiyya Mujaddidiyya in the name of Hayy, Qayyum, Qabhär (Allah's name); they only make dbikr in the name of Allah. According to Sirhindi, Bahā' al-Dīn al-Naqshabandī, he means by saying: "We attribute the end in the bid" $a$ " (we include the end in the beginning). Because some other sect members first turn to the attributes of Allah and then to $d h \bar{a} t$, while Naqshabandīs turn to dhat from the start. Therefore, the last method of the others is the first method of the Naqshabandiyya. According to Imam-i Rabbani, the purpose of dhikr is to remove heedlessness from the heart. Also, dhikr is not just to read certain words. The exchange concerning the religious rules and customs is also considered a remembrance. ${ }^{74}$ Likewise, saving a community from falling into a hole in the road is just like dhiker, it is even more virtuous. However, dbikr made by mentioning the names and attributes of Allah is very effective and creates love for Allah and conveys it to him quickly.

Imam Rabbani says the following regarding this issue:

"O, my son! Opportunity is a blessing. We should also spoil leisure time and must spend our time chanting (dhikr) the Allah Almighty. Everything that is done following the supreme sharia (religious rules), even if it is shopping, is considered dhikr. In all our situations and movements, please abide by the religious provisions so that all of them are considered dhikr. Indeed, dhikr means to destroy heedlessness. All things necessary to follow Allah's orders and avoid its prohibitions are included in the dhikr. However, dhikr made with the name of Allah personally affects more quickly, gives birth to His love, and brings him together quickly.",75

According to Imam Rabbani, when he says Lä iläha (there is no other god) in the remembrance of al-nafy wa al-ithbät (Là iläha illa Allah), he should take out the gods of his desires from the heart, know Allah as the only Allah, love him, he must be willing to his discretion. When he says illa Allah (there is only Allah), he should turn

\footnotetext{
${ }^{73}$ Marcia Hermansen and Arthur F. Buehler, "Sufi Heirs of the Prophet: The Indian Naqshbandiyya and the Rise of the Mediating Sufi Shaykh", Journal of the American Oriental Society 120, no. 1 (2000), 114.

74 Tosun, "İmam-i Rabbani Ahmed Sirhindi", 52.

${ }^{75}$ Ibid., 53.
} 
to Allah's essence and not think of anyone other than His essence. The possessions in the world are lost when a person dies. Therefore, the Sufi should take them out of his heart while he is alive. The purpose of the dhikr (remembrance) of al-nafy wa al-ithbät is to destroy the false deities (outside and Inside Man). The false gods on the outside are idols like Lat and Uzza. The false deities inside are the desires of the soul. ${ }^{76}$

The dhikr in the Mujaddidiyya branch of the Naqshabandiyya, which continued after Imam Rabbani, dhiker is performed not in a dhiker jali (soundly dbikr) manner, but in a dhiker khafi (silent dhikr). Therefore, Imam Rabbani gave importance to dhikr khafi rather than dbikr jali. ${ }^{77}$ In Islam, there are licenses and perseverance. According to Imam Rabbani, the dhikr jabri (soundly dhikr) is the license. The dhiker khafi (silent dhikr) is perseverance. Because Naqshbandiyya tariqa preferred the path of determination, they based dhikr khafi. Although it is more virtuous to perform the dhikr with ablution, he suggested some supplications and dhikr in a letter he wrote to one of his disciples, adding that it is unnecessary to make ablution to read them. ${ }^{78}$ According to Imam Rabbani, it is not required to close the eyes during dhikr. However, he thinks that it is more beneficial to close the eyes until the dhikr becomes the habit of the heart. In the dhiker of ism al-dhät (ism-i celäl, Allah), the sälik should initially focus on his heart and say the name "Allah" on his heart. During this dhikr, he should not deliberately move his limbs (except for his spontaneous movements under the influence of $d b i k r) .^{79}$

Imam Rabbani banned sam $\bar{a}^{-}$and all kinds of music to increase Ishq-i-Ilahi. However, some branches of the Mujaddidiyya Tariqa places more emphasis on dhiker jali. Moreover, they do the Hamd and Naat $\left(\operatorname{sam}^{a}\right)$ without music.

\footnotetext{
${ }^{76}$ Sheikh Ahmad Sirhindi, Ma'ârif-i Ledünniyye (Karachi: Iqbal Review, 1388/1968), 48.

77 Akhtar Qambar, "Fundamentalism or a Return to Fundamentals? A Study of Naqashbandi Tariqa", Islam and the Modern Age XX, no. 2 (1989).

78 Tosun, "İmam-i Rabbani Ahmed Sirhindi", 53.

79 Ibid., 54; Irfan M. Khan, "Recentering the Sufi Shrine: A Metaphysics of Presence" (PhD diss., Harvard University, Graduate School of Arts and Sciences, 2019), 106.
} 


\section{Kashf, Ilham, and Karāma}

The Kashf, which refers to revealing as a word, is defined as abolishing the veil of body and feeling and watching the spirit world as a vision of the imagination. The believer sees the unseen behind a thin covering (through symbols) basing on this and similar verses and hadiths. Those who know the inherent knowledge of the Sufis become acquainted with the unseen. It is claimed that this is not contrary to the verse, "The overlooked keys are next to Him."

They know these unseen matters not with their human bodies but by passing through the human body and acquiring the attributes of the truth. So, they are not with themselves but with Allah. They see and know through the sight of Allah. When they live in Allah, Allah entrusts them with their adjectives. They look through the eyes of Him; even if they look with Him, distance and proximity become one, walls are not curtaining. ${ }^{81}$ In this way, the information opened to man is called kashfi knowledge. The kashf is divided into waby (revelation) and ilham (inspiration). This walaya (guardianship) is in terms of nubuwwa (prophethood). For, Bukhārī is stated in the hadīths of Rikak: "When I love my servant, I become his holding hand, the eye that sees, the speaking tongue, the hearing ear, the walking foot." ${ }^{\prime 2}$

Imam Rabbani evaluates the kashf as follows: "The sharia provisions depend on four pieces of evidence. There is no place for kashf among them. However, there are many religious affairs beyond the requirements of sharia, in which kashf exists as the fifth essential. ${ }^{83}$ However, according to him, ilhäm cannot determine whether something is wrong or correct. The statement in his letter on this subject is as follows: "For the person who desires to be a dervish, at the beginning of the conditions of the sect is to adopt the principles of belief that the scholars of Ahl al-Sunna wa al-Jamā'a revealed from the Qur'ān and Sunna. It is also one of the necessities of this way to understand the story of the Qur'ān and Sunna within the framework of the meaning that those scholars interpreted and not to enter any other interpretations. For example, suppose different meanings are born to his heart by way of kashf and ilhäm. In that case, it is necessary

\footnotetext{
${ }^{80}$ Al-Qur’ān, 6:59.

${ }^{81}$ Cebeceoğlu, Tasavvuf Taribi, 334.

82 al-Bukhārī, Saḥīh al-Bukhārì, Hạaīth 25, 40 Hadīth Qudsi.

${ }^{83}$ Cebeceoğlu, Tasavvuf Taribi, 335.
} 
to rely on those of the scholars and take refuge in Allah from his discovery. ${ }^{84}$

To prefer kashf and ilhäm to scholars' opinions means choosing certain judgments sent by Allah, which means perversion and harm itself. Although the various works describing the saints are competent in the literature, the mystical deeds (karamāt) are regarded as permanent directions. Imam Rabbani continued the same understanding. The greatest miracle: it is to live the Qur'ān in the dimension of piety.

According to Imam Rabbani, kashf and karäma are Allah's gifts. He honors someone with kashf and karama and bestows this blessing. Sometimes, a high-status person is seen in society, but kashf and karama do not show up. Miracles are given to enhance the strength of human beings. Pir-muridi is a process where there is no need for Karamat and extraordinary events. Allah gives it to human needs. He further thinks that the saints are those who call people to Allah. They are Allah's mercy. They work for the peace of human society on earth. ${ }^{85}$ To sum up, it is seen as a cautious approach in accepting inspiration, especially when it comes to seeing it as a source of authentic information.

\section{Concluding Remarks}

In the second millennium A.H., the great reformer and spiritual saint Imam Rabbani became known as Mujaddid-e Alf-e Sani. In the same way, he continued the religion's pure teachings by dispelling the superstitions of the Islamic sharia, introducing a new type of Sufi teachings in the spiritual world called the "Mujaddid Tariqa". His struggling and religious life were colorful, eventful, and a role model for Muslims. ${ }^{86}$ The Mughal emperors faced many feuds during the reigns of Akbar and Jahangir. He struggled to attract state administration to pure Islam. As a result of his sincere efforts, pure Islamic ideology spread to different parts of the subcontinent, fearless faith and absolute reliance on Allah acts as an essential supporting

\footnotetext{
${ }^{84}$ Khan, "Recentering the Sufi Shrine", 107.

85 Aziz Khan, Harrat Mujaddid Alfe Sani, 270.

${ }^{86}$ Muhammad Yasin Mazhar Sidiqui, "The Role of 'Ulama in the Spread of Islam in the Indo-Pak Sub-Continent-A Critical Appraisal”, Journal of Objective Studies 3, no. 1 (1991).
} 
force. ${ }^{87}$ Imam Rabbani's thoughts mainly influenced Yahya, Shah Rafi Uddin, and Shah Syed Ahmad Barelvi, Shah Waliullah, Khwaja Mir Nasir, Khwaja Mir Darad, Ghulam, and many other Sufi saints. ${ }^{88} \mathrm{He}$ protected Islam from the influence of Greek philosophy and the power of local infidels. Moreover, He was able to bring an authentic reflection of the Qur'ān and Sunna among the people of the Indian subcontinent through Sufism. His struggling life's teachings and ideals inspired Muslims to follow the path of truth, welfare, and justice.

\section{Bibliography}

Abu Sa'id Nur al-Din, Wabdat al-Wujud and Falsafa Khudi. Karachi: Iqbal Review, 1962.

Affifi, A.E. The Mystical Philosophy of Mubyiddin ibn al-'Arabi. UK: Cambridge University Press, 1939.

Afifi, Ebu'l-Alā. Mubyiddin İbn Arabìnin Tasavvuf Felsefesi, trans. Mehmet Dağ. Ankara: AÜİFY, 1975.

Alam, Muzaffar. "The Mughals, the Sufi Shaikhs and the Formation of the Akbari Dispensation", Modern Asian Studies 43, no. 1, 2009.

Alfi, Sajida. "The Naqshbandi Mujaddidi Sufi Order's Ascendancy in Central Asia through the Eyes of its Own Masters and Disciples $\left(17^{\text {th }}\right.$ to $19^{\text {th }}$ Century)", in Todd Lawson (ed.), Reason and Interpretation in Islam: Theology, Philosophy, and Mysticism in Muslim Thought. London: I. B. Tauris, 2005.

Amin, Muhammad Ruhul. Mujaddid-i Alfesani's Reform Movement. Dhaka: Islamic Foundation Bangladesh, 1984.

Ansari, Abdul Haq. "Ibn 'Arabī: the Doctrine of Wahdat al-Wujūd', Islamic Studies 38, no. 2, 1999.

Ansari, M. Abdul Haq. "The Life and Mission of Shaykh Ahmad Sirhindî”, Islamic Culture 59, no. 2, 1985.

----. Sufism and Shari'ah. London: Islamic Society, 1986.

Aslam, Muhammad. "Jehangir and Hadhrat Sheikh Ahmad Sirhindi", Journal of Asiatic Society of Pakistan, June 1, 1965.

-----. Din llahi aur Is Ka Pasmanzar. Delhi: Besturdubooks, 1969.

\footnotetext{
${ }^{87}$ Siddique, Din-i-Ilabi, 63.

88 Saeyd Raashed Hasan Chowdury, "Bangladeş’te Tasavvuf Kültürü ve Temsilcileri”, in Ahmet Cahid Haksever, Tematik Tasavvuf Toplantılar Fikriyat Kişiler Kurumlar, Vol. 2 (Ankara: Sonçă̆, 2019), 33-52.
} 
Aziz, A.F.M. Abdul and Khan, Siddique Ahmed. Harrat Mujaddid Alfe Sani. Dhaka: Islamic Foundation Bangladesh, 2001.

Aziz, Ahmad. Hind wa Pak Main Islami Culture. Delhi: Islamic Cultural Society, 1991.

Bilgin, İbrahim Ethem. Devrimci Süfì Haraketleri ve İmam-i Rabbānì. İstanbul: Kültür Basın Yayın Birliği, 1989.

Bisati, Afroz Ahmad. Sherkh Ahmad Sirhundi's Thought and its Impact on The Development of Sufism. Srinagar: Shah-i-Hamdan Institute of Islamic Studies The University of Kashmir press, 2001.

Buehler, Arthur F. "Aḥmad Sirhindī: A $21^{\text {st }}$ Century Update", Der Islam: Journal of the History and Culture of the Middle East 86, no. 1, 2011.

-----. "The Naqshabandiyya in Tìmūrid India: the Central Asian Legacy", Journal of Islamic Studies 7, no. 2, 1996.

----. Revealed Grace: The Juristic Sufism of Abmad Sirbindi (1564-1624). Louisville, KY: Fons Vitae, 2011.

----. "Sharī'at and 'Ulamā in Ahmad Sirhindī's Collected Letters", Die Welt des Islams 43, no. 3, 2003.

Bukhārī (al), Abū 'Abd Allāh Muḥammad b. Ismā̄îl. Sahịị al-Bukhārì, Hadīth No. 2697. Beirut: Dār al-Fikr, 2003.

Cebeceoğlu, Ethem. Tasavvuf Taribi: Imam-i Rabbānì ve Vabdet-i Şubūd Anlayısıı. Ankara: Ankara Üniversitesi Uzak Tan Eğitim Yayınları, 2013.

Cebecioğlu, Ethem. İmam-i Rabbani Hareketi ve Tesirleri. İstanbul: Erkam Yayınları, 1999.

Chowdury, Saeyd Raashed Hasan. "Bangladeş’te Tasavvuf Kültürü ve Temsilcileri", in Ahmet Cahid Haksever, Tematik Tasavvuf Toplantılar Fikriyat Kişiler Kurumlar, Vol. 2. Ankara: Sonçağ, 2019.

Chowdury, Saeyd Rashed Hasan. "Bangladeş’te Tasavvufun ve Tarikatların Değerlendirilmesi, Sosyal Gelişimleri ve Oynadıkları rol: Yirmi Birinci Yüzyılda bir vak'a Incelemesi”. Ankara: Ankara University, 2019.

Faruqi, Abdul Shakoor. Imam Rabbani: al-Furqan-Mujddid Alf Thani. Lucknow: Academia, 1961.

Faruqi, Burhan Ahmad. The Mujaddid's Conception of Tawbid. Delhi: Nabu Press, 1977.

Foster, William. Early Travels in India. United Kingdom: Oxford University Press, 1921. 
Friedmann, Yohanan and Haar, J. G. J. Ter. "Follower and Heir of the Prophet: Shaykh Ahmad Sirhindī (1564-1624) as Mystic", Journal of the American Oriental Society 114, no. 3, 1994.

Göktaş, Vahit and Chowdury, Saeyd Rashed Hasan. "Freedom of Religion, Faith and Religious Tolerance in Bangladesh: A Case Study on the Islamic Mysticism", Disiplinlerarasi Sosyal Bilimler Dergisi 5, 2019.

Hermansen, Marcia and Buehler, Arthur F. "Sufi Heirs of the Prophet: The Indian Naqshbandiyya and the Rise of the Mediating Sufi Shaykh", Journal of the American Oriental Society 120 , no. $1,2000$.

Hossain, Mohammad Israfil. Mujaddide Alfe Sunny Rabimabullah Talks about Life. Dhaka: Alqur'anerpath, 2019.

Iqbal, Allama Muhammad. Reconstruction of Religious Thought in Islam. Delhi: Adam Publishers, 2001.

Kha, Muhammad Akram. Muslim Bonger Samajik Itihas. Oitijjo Prokashoni, Dhaka 2002.

Khan, Irfan M. "Recentering the Sufi Shrine: A Metaphysics of Presence". PhD diss., Harvard University, Graduate School of Arts and Sciences, 2019.

Khan, Kabir. "A Short Bibliography of Shaykh Ahmad Sirhindi", The Muslim World Book Review 12, no. 2, 1992.

Kishmi, Muhammad Hashim. Zubdat al-Maqāmāt. Kanpur: Aligarh Muslim University, 1980.

Kontho, Kaler. Mujaddede Alfe Sani (rh): Songskar Andoloner Kirtiman Mohapurush. Dhaka: Daily Kaler Kantho Newspaper, 2014.

Landau, Rom. The Philosophy of Ibn al-'Arabi. London: Academy, 1959.

Mehta, Nowroze Cooverji. The Religious Policy of Akbar. Delhi: Otichco Prokahsoni, 1966.

Nodovi, Masud Alam. Upmohadeshe Islami Andoloner Itihas. Dhaka: Sotabdi Prokashoni, 2002.

Qambar, Akhtar. "Fundamentalism or a Return to Fundamentals? A Study of Naqashbandi Tariqa", Islam and the Modern Age XX, no. 2, 1989.

Rashid, Mamunur. Biography of Harrat Mojadded Alfesani. Dhaka: Dharmapurdarbar, 2018.

Ross, Denison and Power, Eileen. Akbar and the Jesuits, trans. C.H. Payne. Delhi: De Gruyter, 1979. 
Roychoudhary, M.L. Din-i-Ilabi (The Religion of Akbar). Delhi: Tezpur University, 1985.

Sani, Hazrat Mujaddede Alfe. Maarife Ladunniya. Narayangonj: Mujaddediya Kutubkhana, 2012.

Siddique, A. F. M. Abu Bakar. Din-i-Ilabi o Mujaddid Alfe Sani (r). Dhaka: Islamic Foundation Bangladesh, 1991.

Siddiqui, KS. Mojaddedde Alfesani (Rah.) and Emperor Jahangir. Dhaka: Dailyinqilab Newspaper, 2016.

Sidiqui, Muhammad Yasin Mazhar. "The Role of 'Ulama in the Spread of Islam in the Indo-Pak Sub-Continent-A Critical Appraisal”, Journal of Objective Studies 3, no. 1, 1991.

Sijistānī (al), Abū Dāwud Sulaymān b. al-Ash'ath b. Ishạāq al-Azdī. Sunan Abì Dāwnd, "Kitāb al-Malāhim", Vol. 4. Egypt: Maktaba Sharika and Maktabat al-Muștafā, 1952.

Sirhindi, Sheikh Ahmad. Ma'ärif-i Ledünniyye. Karachi: Iqbal Review, 1388/1968.

----- Risäla Tahliliyya (Arabic text with Urdu tr., Dr. Gh. Mustafa Khan). Karachi: Iqbal Review, 1965.

-----. Sharb-i-Rubäiryat (Persian text with Urdu tr., Dr. Gh. Mustafa Khan). Karachi: Iqbal Review, 1966.

Sunar, Cavit. Vahdet-i Subüd-V abdet-i Vü̈ūd Mes'elesi. Ankara: Anadolu Aydinlanma Vakfi Yay, 1960.

Tosun, Necdet. "İmām-i Rabbānī (K.S.)'nin Tasavvufì Görüşleri Tasavvuf Yoluna Giriş Ve Zikir", Somuncu Baba Dergisi 239, 2009.

-----. Imam-i Rabbani Abmed Sirbindi. İstanbul: Insan Yayınları, 2005.

Valiuddin, Mir. "Reconciliation between Ibn al-'Arabi's Wabdat - $i$ Wujud and the Mujaddid's Wabdat-i-Shubud", Islamic Culture 25, no. 1-4, 1951.

Voll, John O. "Renewal and Reform in Islamic History: Tajdid and Islah," Voices of Resurgent Islam, 1983.

Weismann, Itzchak. "Indian Roots of Modern Islamic Revivalism", Journal of South Asian and Middle Eastern Studies 36, no. 4, 2013. 